\title{
Investment Analysis of Photovoltaic Roof Project Based on Real Option
}

\author{
Pengbo Yang ${ }^{1}$, Xinyue $\mathrm{Ma}^{2}$, Hao Luo ${ }^{3}$ \\ 1, 2, 3 Xidian University, School of Economics and Management, Xi Feng Road, Xinglong Section 266, Xi'an, Shaanxi Province, China1
}

\begin{abstract}
In the context of the increasingly sharp national energy security problems and the lack of fossil energy, distributed photovoltaic power generation is of great significance to promote the transformation of China's energy structure. This paper firstly analyzes the commercial model, the cost and benefit of distributed photovoltaic power generation, then puts forward the crowd-funding method of financing the PV project to overcome the difficulties of photovoltaic power generation project financing. Finally, the real option theory is applied to the investment evaluation, and the quantitative analysis is carried out by using the Black-Scholes pricing formula. It is pointed out that the real option theory can better evaluate the investment value of the project.
\end{abstract}

Keywords: Distributed roof photovoltaic, Real option, Crowd-funding, investment benefit

This study was supported by the Fundamental Research Funds for the Central Universities (ID: JB160607)

\section{Introduction}

Energy is the material basis for people's survival and reproduction and social prosperity. It is also an important material source for the development of national economy. Modern agriculture, industry, national defense, transportation and so on are relying on a large amount of energy consumption as a source of support and power. But for a long time, China's economic development depend too much on enlarging the scale of investment and increase input, with resource and environmental issues is more and more sharp, resource depletion and environmental pollution has become the bottleneck of restricting China's economic long-term growth. Economic development is highly depend on energy that determines the country in order to obtain economic development must first ensure adequate supply of energy, the country's energy security has become one of the major issues that should be given priority in national decision-making.

Energy security ensure the sustainable development of national, and conversely, energy insecurity will lead to damage the economy and society, a series of problems occurred, but the total global energy reserves is limited and it cannot guarantee all the existing mode of long-term energy consumption, therefore, how to use the new energy to protect the stable development of the country has become an important issue.

The exploitation and utilization of fossil energy, such as coal and oil, not only results in over exploitation and tight supply, but also leads to a series of environmental problems. Therefore, in the future energy strategy, pollution-free and recyclable new energy will be the primary choice.

At present, China's major power supply is still relying on fossil fuels to generate electricity, not only need to consume a lot of coal resources and water resources and other non-renewable resources, and will discharge a lot of pollutants. The new energy power generation refers to the wind energy, water, solar energy, biomass, geothermal, nuclear energy and other clean and renewable characteristics of energy into electricity ${ }^{[1]}$. Because the power generation process does not produce or rarely produce environmentally harmful emissions and do not need to consume fossil fuels, so this power generation not only save non-renewable energy, but also improve the environment. In 2011, the United Nations Intergovernmental Panel on Climate Change (IPCC) assessed six renewable energy resources (bio-energy, solar, geothermal, hydro, ocean, and wind). The results show that the solar energy resources development potential is the highest of all renewable energy.

\section{Distributed Photovoltaic Power Generation}

\subsection{Distributed roof photovoltaic power generation}

Distributed photovoltaic power generation is a kind of clean energy generation, and the construction time is short. You not only can make full use of the roof space, but also the process of operation and maintenance is relatively easy. In addition, the distributed photovoltaic power generation is generally close to the user, the power generation location is to absorb the location, without long-distance transmission, can greatly improve the efficiency of energy use, and anti-interference ability is particularly strong. This will greatly reduce the energy consumption generated during transmission.

The distributed rooftop photovoltaic power station system uses the photovoltaic modules (batteries) installed on the roof of buildings to convert light energy to direct current and to converge. Then, through the grid connected inverter, the DC power is converted into an alternating current with the same frequency and phase of the grid, and then connected to the distribution system of the user side. Photovoltaic power plants mainly supply power to the roof users $^{[2]}$.

With the development of solar photovoltaic technology, distributed photovoltaic power generation has become quite common and mature in Europe and America ${ }^{[3]}$. The 


\section{International Journal of Science and Research (IJSR) \\ ISSN (Online): 2319-7064}

Index Copernicus Value (2015): 78.96 | Impact Factor (2015): 6.391

proportion of photovoltaic construction applications in Germany, Italy and other countries has reached more than $80 \%$, and the development of foreign solar photovoltaic power generation industry has a good guiding role for China's photovoltaic power generation industry. China is rich in solar energy resources. According to China's distribution of solar energy resources, most areas of China are suitable for the development of solar photovoltaic industry. Because of China's urban population and land shortage, the roof photovoltaic power generation system become a substitute for ground photovoltaic power plants

\subsection{The business model of photovoltaic power generation}

\subsubsection{Unified purchase and marketing model}

The third party investment is responsible for the investment, construction and operation and maintenance of photovoltaic power generation, enjoy the right to operate photovoltaic power generation, all the power generation into the public power grid, power supply enterprises responsible for the full acquisition of photovoltaic power generation. In this mode, investors will receive government subsidies:1) in subsidies to build the power station, the generators will sell the power to the power grid enterprises in accordance with the benchmark price of the coal-fired desulfurization unit; 2) in the electricity price subsidies, the generator in accordance with the benchmark price of electricity will sell the power to the power grid enterprises, without bearing the network charges and spare costs ${ }^{[4]}$.

\subsubsection{Contract energy management model}

Contract energy management model, that is, third-party investors to invest in the construction of photovoltaic power supply. The power generation priority to meet users who is the same location with the photovoltaic power, the excess power is on the grid, the power shortage will be supplied to the users by the power grid enterprise according to the local sale price. In this mode, photovoltaic power generation is converted to the low voltage power grid directly to the users, and the investors receive the government subsidies according to the total electricity consumption. According to the local coal desulfurization unit benchmark price, the excess power will be acquired by the power supply enterprise, and the power supply enterprise will charge the user according to the local catalog price.

\subsubsection{Self-use mode}

Self-use mode, that is, the user to build their own photovoltaic power plant, the power generation priority for their own use, the excess power on the grid, the lack of electricity provided by the grid. The distributed power supply and the user are located at the same location. In this mode, the user power generation priority for their own use, the excess power shall be sold to the power grid enterprises according to the benchmark price of the local coal-fired desulfurization unit. At the same time, according to the total amount of electricity to obtain government subsidies

\section{Analysis on the Crowd-funding Financing Mode of Rooftop PV System}

Traditional banks are not active in the distributed PV project because of the long payback period of the distributed PV power plant, the uncertainty of the return rate and the small scale of investment. It is possible to use the Internet banking, which uses crowd-funding model for financing to promote the construction of distributed photovoltaic solve its financing bottleneck ${ }^{[5]}$.

\subsection{Cases of crowd-funding}

Mosaic Company has raised \$6 million through crowd-funding model to raise financing for about $18 \mathrm{MW}$ of independent rooftop photovoltaic projects. The Mosaic Company through the network platform to raise public investors, some information items such as installation, power generation, the loan period, the interest rate and the lender will open to the public. Mosaic for two-way charges, on the one hand to the project owners to collect loan fees, on the other hand to investors $1 \%$ of the platform annual fee charged. Owners and service providers signed a fixed 20-year fixed low-cost electricity contract. The expected annual yield of $4.5 \%$ for Mosaic Company projects (including management fees), for small and medium-sized investors yields higher than the same period of the market most investment products (us 30 year Treasury rate was only $2.5 \%$ ).

\subsection{Analysis of the crowd-funding mode}

Compared with the traditional bank credit financing, equity financing and bond financing, through crowd-funding mode raising funds to raise a wider audience, measuring the ability to raise funds is not just the commercial value of the project. Many investors invest in photovoltaic projects is not just for investment income, but to promote the concept of environmental protection as the original intention, so that energy-saving emission reduction, everyone involved. Compared with the traditional PV power plant financing model, investors are no longer just income-oriented, more began to consider the nature of public welfare.

If the distributed roof PV project adopts the crowd-funding mode, through the Internet financial innovation, avoiding the cumbersome and lengthy approval process of the state-owned banking system and the current bank's overall loan restrictions on the PV industry, while providing investors with higher-than-expected interest rates. As a result, it is proposed to alleviate the bottleneck of distributed PV power plant construction through crowd-funding mode.

For example, a third-party company as the power station's initiator and operator, while providing some financial support. And cooperating with the Internet financial platform, such as crowd-funding platform, launching for the power station of the special financing projects, the majority of the public through the network subscription, financing scale can be set according to the size of power plants, and the investor obtains the corresponding shares of the power 


\section{International Journal of Science and Research (IJSR) \\ ISSN (Online): 2319-7064}

Index Copernicus Value (2015): 78.96 | Impact Factor (2015): 6.391

station according to the investment amount. During the fundraising period, cooperate with the insurance company to insure the power station quality, operation and power generation, further reduce the risk and increase the attractiveness to the ordinary investors.

Using Internet banking, first of all, its audience wide making small funds can be accumulated into large investment; Secondly, it can avoid the legal risks of illegal fund-raising. Although the return rate of photovoltaic power plants is not attractive to traditional fund companies, the return on investment is quite attractive to ordinary investors.

\section{Cost Analysis of Rooftop Photovoltaic Systems}

\section{(a)Initial investment}

The cost is mainly composed of photovoltaic modules, grid connected inverters, cables and brackets, accessories and other expenses. Among them, the PV module is the main investment spending.

\section{(b)Renovation and maintenance costs of photovoltaic equipment}

The life of photovoltaic modules is about 25 years. The grid connected photovoltaic power generation system does not require a storage battery, and the PV module updating and the maintenance cost of the battery are not necessary. Inverters and other electrical equipment in the life cycle only need to be partially updated to maintain the normal operation of photovoltaic projects.

\section{(c)Annual operation and maintenance costs}

In the process of operation of photovoltaic power plants every year will have a certain operation and maintenance costs, including caregivers wages, equipment maintenance costs. PV power plants accept solar power, there is no fuel costs, so the cost of maintenance than other types of power plants.

\section{Benefit Analysis of Rooftop Photovoltaic System}

\section{(a)Power generation benefits}

Calculate the economic benefits, we not only to consider the annual power generation and electricity price factors, but also need to take the country's encouragement to distributed photovoltaic power generation into account. As long as the construction of a distributed photovoltaic power generation, you can get the corresponding subsidies in accordance with the installed capacity, the current subsidy is $0.42 \mathrm{RMB}$ per kWh.

Suppose that Q is an annual generating capacity of unit kWh; $\mathrm{P}$ is the purchase price of the surplus Internet, in units of $\mathrm{RMB}$; $\mathrm{R}$ for government subsidies, units for three $\mathrm{RMB}$ $/ \mathrm{kWh} ; \mathrm{P}_{1}, \mathrm{P}_{2}$ and $\mathrm{P}_{3}$ represent the three step price of the market respectively, and $\mathrm{Q}_{1}, \mathrm{Q}_{2}$ and $\mathrm{Q}_{3}$ represent the three steps of the market respectively.

(1) $100 \%$ into the grid
In the case of $100 \%$ power generation into the grid, it means that all the power of distributed photovoltaic power generation is on the grid, no use. The annual economic benefits are calculated as:

$\mathrm{S}_{100}=\mathrm{Q} \times \mathrm{P}+\mathrm{Q} \times \mathrm{R}$

\section{2) $50 \%$ into the grid, $50 \%$ for personal use}

In this case, $50 \%$ of the annual electricity generation into the grid, according to the remaining electricity into the grid purchase price to calculate. For $50 \%$ of their own use, due to the savings of the use of large power grid, this part of the cost should also be counted as the benefits of distributed photovoltaic power generation. In the calculation of this part of the proceeds, according to the local level of the corresponding price and electricity to calculate. The annual economic benefits are calculated as:

$\mathrm{S}_{50}=\frac{\mathrm{P} \times \mathrm{Q}}{2}+\mathrm{Q} \times \mathrm{R}+\mathrm{P}_{1} \times \mathrm{Q}_{1}+\mathrm{P}_{2} \times \mathrm{Q}_{2}+\mathrm{P}_{3} \times \mathrm{Q}_{3}$

3) $100 \%$ for personal use

In this case, due to the savings of the use of large power grid, this part of the cost should also be counted as the benefits of distributed photovoltaic power generation. In the calculation of this part of the proceeds, according to the local level of the corresponding price and electricity to calculate. The annual economic benefits are calculated as:

$\mathrm{S}_{0}=\mathrm{Q} \times \mathrm{R}+\mathrm{P}_{1} \times \mathrm{Q}_{1}+\mathrm{P}_{2} \times \mathrm{Q}_{2}+\mathrm{P}_{3} \times \mathrm{Q}_{3}$

\section{(b) Environmental benefits}

The energy efficiency of distributed photovoltaic power generation is mainly reflected in the reduction of conventional energy consumption during operation. Its environmental benefits mainly mean that the power generation process does not emit harmful gases.

Using "carbon emissions trading" to measure environmental benefits. The concept of carbon emissions includes two categories, one is the carbon emissions required by an enterprise, and the other is the amount of carbon that the enterprise can use. Through the two indicators to do worse, you can get carbon emissions gap. If the difference is positive, then the enterprise needs to buy some carbon emissions, or to receive government punishment, if the difference is negative, then the enterprise can sell the remaining carbon emissions to other enterprises, and get a certain income. Through this mode, the environmental benefits of the distributed PV generation project can be converted to the actual money inflow, as long as the trading price of the carbon emission permits can be determined.

\section{Real Option Analysis}

\subsection{Real option and its pricing model}

Real options refer to under uncertain conditions options for investing in physical assets similar to financial options. Real option method is a new way of thinking about investment decision-making [6]. The traditional investment decision-making method ignores the financial structure of 


\section{International Journal of Science and Research (IJSR) \\ ISSN (Online): 2319-7064}

Index Copernicus Value (2015): 78.96 | Impact Factor (2015): 6.391

the enterprise, but also does not take into account the development of enterprise strategic planning, but the real option theory discusses how decision-making can increase the value of project. Thus, even if the real option method can not accurately price a physical asset, it provides investors with an investment decision-making tool that takes into account the strategic development plan of the firm.

The real option is more European style option, and the most widely used real option pricing model is the Black-Scholes pricing model, as follows:

$\mathrm{C}=\mathrm{S} N\left(d_{1}\right)-K e^{-r t} N\left(d_{2}\right)$

$$
\begin{gathered}
d_{1}=\frac{\ln \frac{S}{K}+\left(r+\frac{\sigma^{2}}{2}\right) t}{\sigma \sqrt{t}} \\
d_{2}=d_{1}-\sigma \sqrt{t}
\end{gathered}
$$

Where $\mathrm{C}$ is the current value of the option; $r$ is the non-risk interest rate of the asset within the validity period of the option; $\mathrm{K}$ is the option execution price; $\mathrm{S}$ is the underlying asset value; $\mathrm{t}$ is the option expiration time; $\mathrm{N}$ is the cumulative normal distribution function; $\sigma$ is the underlying asset volatility.

\subsection{Real Option Pricing in Decision-making of Investment Project in Distributed Photovoltaic Power Generation Project}

Due to the high uncertainty about the investment income of the distributed PV project in the contract energy management mode, therefore, this paper takes into account the real option pricing model in the investment decision of distributed photovoltaic power investment project.

According to the characteristics of the distributed PV project, the relevant parameters in the Black-Scholes pricing model are modified to meet the needs of the distributed PV project investment decision.

\begin{tabular}{|c|c|}
\hline parameter & Corrected parameters \\
\hline $\begin{array}{c}\text { The value of the underlying } \\
\text { asset }(\mathrm{S})\end{array}$ & $\begin{array}{c}\text { Current market value of } \\
\text { distributed PV projects }\end{array}$ \\
\hline $\begin{array}{c}\text { The execution price of the } \\
\text { option }(\mathrm{k})\end{array}$ & Cost of distributed PV projects \\
\hline The duration of the option $(\mathrm{T})$ & $\begin{array}{c}\text { The final time in which an } \\
\text { investor makes an investment } \\
\text { decision }\end{array}$ \\
\hline $\begin{array}{c}\text { Risk-free interest rate }(\mathrm{r}) \\
\text { Volatility of underlying assets } \\
(\sigma)\end{array}$ & $\begin{array}{c}\text { Short-term treasury bond } \\
\text { interest rates }\end{array}$ \\
\hline
\end{tabular}

In the contract energy model, the PV power station is usually built by a third party, taking the roof PV project as an example, the power generated by the rooftop photovoltaic power plant built by the housing developer can be sold to the landlord by contract, or they can also choose all power into the grid or part of the power into the grid, and the contract is negotiated by the developer and the owner to distribute the proceeds.

\subsection{Empirical analysis}

The case simulates a rooftop photovoltaic power generation system in a large residential district (or university) in Xi'an, with a planned installed capacity of $3 \mathrm{MW}$.

Using the contracted energy management model described above, that is, third-party investors to invest in the construction of photovoltaic power, and project funds through crowd-funding for the masses of people raised. The power generated by rooftop photovoltaic power stations can be sold to the owners at fixed low prices by contract, or they can also choose all power into the grid or part of the power into the grid, and the contract is negotiated by the developer and the owner to distribute the proceeds.

\subsubsection{Calculation of costs and benefits}

(a)The power generation integrate into the power grid estimation. When the PV module has a tilt angle of 35 degrees, the solar energy received by the inclined plane is the largest. Considering annual attenuation rate, the annual power generation according to the optimum fixed inclination angle is shown in table 1.

\begin{tabular}{|c|c|}
\hline \multicolumn{2}{|c|}{ year (25 years) } \\
\hline Year & Power generation \\
\hline 1 & 3850 \\
\hline 2 & 3812 \\
\hline 3 & 3773 \\
\hline 4 & 3734 \\
\hline 5 & 3695 \\
\hline 6 & 3656 \\
\hline 7 & 3617 \\
\hline 8 & 3578 \\
\hline 9 & 3540 \\
\hline 10 & 3500 \\
\hline 11 & 3475 \\
\hline 12 & 3449 \\
\hline 13 & 3422 \\
\hline 14 & 3397 \\
\hline 15 & 3371 \\
\hline 16 & 3345 \\
\hline 17 & 3319 \\
\hline 18 & 3293 \\
\hline 19 & 3267 \\
\hline 20 & 3241 \\
\hline 21 & 3216 \\
\hline 22 & 3189 \\
\hline 23 & 3163 \\
\hline 24 & 3138 \\
\hline 25 & 3112 \\
\hline
\end{tabular}

Table 1: Photovoltaic power generation (MWh) year by

(b) Cost analysis

(1)Cost calculation parameters of photovoltaic power generation

First, Cost calculation parameters during construction period: construction costs, other construction costs, 


\section{International Journal of Science and Research (IJSR) \\ ISSN (Online): 2319-7064}

Index Copernicus Value (2015): 78.96 | Impact Factor (2015): 6.391

equipment purchase and installation costs, reserve fees

Second, Cost calculation parameter during operation period:

Number of workers in power stations: 4;

Employee salary: $50000 \mathrm{RMB} /$ year;

Maintenance cost rate: percentage of equipment and installation fee $(2 \%)$;

Examine and repair cost rate: percentage of equipment and installation fee (3\%);

Basic parameters of failure cost: percentage of equipment and installation fee (1\%);

Discount rate: discount rate $(6.8 \%)$

Lifetime: 25 years (excluding one year of construction)

Table 2: 3MW distributed PV investment budget table unit: million RMB

\begin{tabular}{|c|c|c|c|c|c|}
\hline Number & $\begin{array}{l}\text { Name of } \\
\text { project or } \\
\text { cost }\end{array}$ & \begin{tabular}{|c|} 
Equipment \\
purchase \\
fee \\
\end{tabular} & $\begin{array}{c}\text { Construction } \\
\text { cost }\end{array}$ & $\begin{array}{c}\text { Other } \\
\text { expenses }\end{array}$ & Total \\
\hline 1 & $\begin{array}{l}\text { Equipment } \\
\text { and } \\
\text { installation } \\
\text { engineering }\end{array}$ & 5034.50 & 1582.28 & & 6616.79 \\
\hline 2 & $\begin{array}{l}\text { Architectural } \\
\text { Engineering }\end{array}$ & & 354.86 & & 354.86 \\
\hline 3 & $\begin{array}{c}\text { Other } \\
\text { projects }\end{array}$ & & & 702.37 & 702.37 \\
\hline 4 & $\begin{array}{c}\text { Basic reserve } \\
\text { fee }\end{array}$ & & & 230.22 & 230.22 \\
\hline 5 & $\begin{array}{c}\text { Static } \\
\text { investment }\end{array}$ & 5034.50 & 1937.14 & 932.59 & 7904.25 \\
\hline
\end{tabular}

Table 3: Operating and management costs related data unit: million RMB

\begin{tabular}{|l|l|}
\hline Operation and maintenance cost category & Total \\
\hline Staff salaries & 500 \\
\hline Maintenance cost & 132.33 \\
\hline Examine and repair cost & 198.50 \\
\hline Failure cost & 66.16 \\
\hline
\end{tabular}

(c) Analysis of investment income

The income of the project mainly includes electricity price income, government subsidy income, saving electricity income and environmental benefits. The annual generation of distributed photovoltaic power generation is shown in Table 1.

In Xi'an, if the monthly electricity consumption of $2160 \mathrm{kWh}$ and below, the standard price is $0.4983 \mathrm{RMB} /$ $\mathrm{kWh}$; electricity consumption of $2161-4200 \mathrm{kWh}$, the price is $0.5023 \mathrm{RMB} / \mathrm{kWh}$; electricity consumption of $4201 \mathrm{kWh}$ and above, the price is $0.5283 \mathrm{RMB} / \mathrm{kWh}$. In Xi'an, people can enjoy $0.88 \mathrm{RMB} / \mathrm{kWh}$ benchmarking price, at the same time in the power generation process, in accordance with the full amount of electricity subsidies for $0.42 \mathrm{RMB} / \mathrm{kWh}$. In the $\mathrm{Xi}^{\prime}$ an area, in order to encourage the construction and distribution of distributed photovoltaic power generation, if the distributed photovoltaic power generation project is put into use and qualified after acceptance, in accordance with installed capacity, the provincial and municipal financial funds were based on the $1 \mathrm{RMB} /$ watt standard, one-time subsidies to investors. Therefore, at the beginning of this project, you can get $6000000 \mathrm{RMB}$ of economic income.

In this case, the power supply of the roof photovoltaic power station is considered to be all into grid, means that all the power of distributed photovoltaic power generation is not for personal use. The electricity price is calculated according to the benchmark price of the region. The photovoltaic power is still available to get subsidies. Then the formula for calculating the economic benefits of first years is:

\section{$3850000 \times 0.88+3850000 \times 0.42=5005000 \mathrm{RMB}$}

Similarly, we can derive economic value from first to twenty-fifth years, as shown in table 4.

Table 4: The economic value of $100 \%$ into the grid

\begin{tabular}{|c|c|c|c|c|}
\hline Number & $\begin{array}{c}\text { Annual power } \\
\text { generation }(\mathrm{kWh})\end{array}$ & $\begin{array}{c}\text { Benchmarkin } \\
\text { g price }(\mathrm{RMB} \\
/ \mathrm{kWh})\end{array}$ & subsidy & $\begin{array}{c}\text { Economic } \\
\text { benefits } \\
(\mathrm{RMB})\end{array}$ \\
\hline 1 & 3850000 & 0.88 & 0.42 & 5005000 \\
\hline 2 & 3812000 & 0.88 & 0.42 & 4955600 \\
\hline 3 & 3773000 & 0.88 & 0.42 & 4904900 \\
\hline 4 & 3734000 & 0.88 & 0.42 & 4854200 \\
\hline 5 & 3695000 & 0.88 & 0.42 & 4803500 \\
\hline 6 & 3656000 & 0.88 & 0.42 & 4752800 \\
\hline 7 & 3617000 & 0.88 & 0.42 & 4702100 \\
\hline 8 & 3578000 & 0.88 & 0.42 & 4651400 \\
\hline 9 & 3540000 & 0.88 & 0.42 & 4602000 \\
\hline 10 & 3500000 & 0.88 & 0.42 & 4550000 \\
\hline 11 & 3475000 & 0.88 & 0.42 & 4517500 \\
\hline 12 & 3449000 & 0.88 & 0.42 & 4483700 \\
\hline 13 & 3422000 & 0.88 & 0.42 & 4448600 \\
\hline 14 & 3397000 & 0.88 & 0.42 & 4416100 \\
\hline 15 & 3371000 & 0.88 & 0.42 & 4382300 \\
\hline 16 & 3345000 & 0.88 & 0.42 & 4348500 \\
\hline 17 & 3319000 & 0.88 & 0.42 & 4314700 \\
\hline 18 & 3293000 & 0.88 & 0.42 & 4280900 \\
\hline 19 & 3267000 & 0.88 & 0.42 & 4247100 \\
\hline 20 & 3241000 & 0.88 & 0.42 & 4213300 \\
\hline 21 & 3216000 & 0.88 & 0.42 & 4180800 \\
\hline 22 & 3189000 & 0.88 & 0.42 & 4145700 \\
\hline 23 & 3163000 & 0.88 & 0.42 & 4111900 \\
\hline 24 & 3138000 & 0.88 & 0.42 & 4079400 \\
\hline 25 & 3112000 & 0.88 & 0.42 & 4045600 \\
\hline Total & & & & 111997600 \\
\hline
\end{tabular}

\section{(d) Environmental benefits}

With reference to each kilowatt-hour reduction of $\mathrm{CO}_{2}$ emissions of $8841.0 \mathrm{~kg}$, it can be seen that the annual reduction of $\mathrm{CO}_{2}$ emissions by distributed photovoltaic power generation is shown in Table 5 .

As the price of carbon emissions trading prices are changing at any time, taking into account inflation, we assume that in the life cycle of distributed photovoltaic power generation, 
International Journal of Science and Research (IJSR)

ISSN (Online): 2319-7064

Index Copernicus Value (2015): 78.96 | Impact Factor (2015): 6.391

the initial carbon price of $25 \mathrm{RMB} / \mathrm{t}$, subsequent price is $25 \times(1+a)^{i}$.

Then we can get the annual environmental benefits of the distributed PV generation as shown in table 5.

Table 5: Environmental benefit value of distributed PV roof project

\begin{tabular}{|c|c|c|c|c|}
\hline Number & \begin{tabular}{|c|} 
Annual power \\
generation \\
$(\mathrm{kWh})$
\end{tabular} & $\begin{array}{c}\text { Carbon } \\
\text { emission price } \\
(\mathrm{RMB} / \mathrm{t}) \\
\end{array}$ & $\begin{array}{l}\text { Annual CO2 } \\
\text { emission } \\
\text { reductions (t) }\end{array}$ & $\begin{array}{c}\text { Economic } \\
\text { benefits } \\
(\mathrm{RMB})\end{array}$ \\
\hline 1 & 3850000 & 25 & 3403.785 & 85094.63 \\
\hline 2 & 3812000 & 27.56 & 3370.1892 & 92882.41 \\
\hline 3 & 3773000 & 34.73 & 3335.7093 & 115849.2 \\
\hline 4 & 3734000 & 36.47 & 3301.2294 & 120395.8 \\
\hline 5 & 3695000 & 38.29 & 3266.7495 & 125083.8 \\
\hline 6 & 3656000 & 40.2 & 3232.2696 & 129937.2 \\
\hline 7 & 3617000 & 42.21 & 3197.7897 & 134978.7 \\
\hline 8 & 3578000 & 44.32 & 3163.3098 & 140197.9 \\
\hline 9 & 3540000 & 46.54 & 3129.714 & 145656.9 \\
\hline 10 & 3500000 & 48.87 & 3094.35 & 151220.9 \\
\hline 11 & 3475000 & 51.31 & 3072.2475 & 157637 \\
\hline 12 & 3449000 & 53.88 & 3049.2609 & 164294.2 \\
\hline 13 & 3422000 & 56.57 & 3025.3902 & 171146.3 \\
\hline 14 & 3397000 & 59.4 & 3003.2877 & 178395.3 \\
\hline 15 & 3371000 & 62.37 & 2980.3011 & 185881.4 \\
\hline 16 & 3345000 & 65.49 & 2957.3145 & 193674.5 \\
\hline 17 & 3319000 & 68.76 & 2934.3279 & 201764.4 \\
\hline 18 & 3293000 & 72.2 & 2911.3413 & 210198.8 \\
\hline 19 & 3267000 & 75.81 & 2888.3547 & 218966.2 \\
\hline 20 & 3241000 & 79.6 & 2865.3681 & 228083.3 \\
\hline 21 & 3216000 & 83.58 & 2843.2656 & 237640.1 \\
\hline 22 & 3189000 & 87.76 & 2819.3949 & 247430.1 \\
\hline 23 & 3163000 & 92.15 & 2796.4083 & 257689 \\
\hline 24 & 3138000 & 96.75 & 2774.3058 & 268414.1 \\
\hline 25 & 3112000 & 101.59 & 2751.3192 & 279506.5 \\
\hline
\end{tabular}

(e) Net present value calculation

Total income $=$ investment income + environmental benefits

+ one-time subsidy

Net Revenue $=$ Total Revenue - Total Cost

Table 6: Project cost and income value Unit: million RMB \begin{tabular}{|l|l|l|l|}
\hline Number & Economic benefits & Environmental benefits Total income \\
\hline
\end{tabular}

\begin{tabular}{|c|c|c|c|}
\hline 1 & 500.5 & 8.51 & 509.01 \\
\hline 2 & 495.56 & 9.29 & 504.85 \\
\hline 3 & 490.49 & 11.58 & 502.07 \\
\hline 4 & 485.42 & 12.04 & 497.46 \\
\hline 5 & 480.35 & 12.51 & 492.86 \\
\hline 6 & 475.28 & 12.99 & 488.27 \\
\hline 7 & 470.21 & 13.50 & 483.71 \\
\hline 8 & 465.14 & 14.02 & 479.16 \\
\hline 9 & 460.2 & 14.57 & 474.77 \\
\hline 10 & 455 & 15.12 & 470.12 \\
\hline 11 & 451.75 & 15.76 & 467.51 \\
\hline 12 & 448.37 & 16.43 & 464.80 \\
\hline 13 & 444.86 & 17.11 & 461.97 \\
\hline 14 & 441.61 & 17.84 & 459.45 \\
\hline
\end{tabular}

\begin{tabular}{|c|c|c|c|}
\hline 15 & 438.23 & 18.59 & 456.82 \\
\hline 16 & 434.85 & 19.37 & 454.22 \\
\hline 17 & 431.47 & 20.18 & 451.65 \\
\hline 18 & 428.09 & 21.02 & 449.11 \\
\hline 19 & 424.71 & 21.90 & 446.61 \\
\hline 20 & 421.33 & 22.81 & 444.14 \\
\hline 21 & 418.08 & 23.76 & 441.84 \\
\hline 22 & 414.57 & 24.74 & 439.31 \\
\hline 23 & 411.19 & 25.77 & 436.96 \\
\hline 24 & 407.94 & 26.84 & 434.78 \\
\hline 25 & 404.56 & 27.95 & 432.51 \\
\hline Total & & & 11643.96 \\
\hline
\end{tabular}

Using the traditional net present value method to calculate $\mathrm{NPV}=11643.96+600-8801.24=34.427$ million RMB

\subsubsection{Option pricing calculation}

The real option theory is used to analyze the investment of the project, investing this project is equivalent to the purchase a call options that a period of 25 years, the price is 8801.24 million RMB. Volatility of underlying assets selects the annual volatility of thermal coal, risk-free interest rate selects rate of YuE Bao.

The cash flow will be discounted at a discount rate of $10 \%$, then we get discounted value is 4358.1 million RMB. So the present value of assets is 4358.1 million $\mathrm{RMB}$

$\mathrm{K}=8801.24, \mathrm{~S}=4358.1, \sigma=22 \%, \mathrm{r}=4 \%, \mathrm{t}=25$.

Using the Black-Scholes pricing formula:

$$
d_{1}=\frac{\ln \frac{4358.1}{8801.24}+\left(0.04+\frac{0.22^{2}}{2}\right) \times 25}{0.22 \times \sqrt{25}}=0.82
$$

$d_{2}=0.82-0.22 \sqrt{25}=-0.28$

$N\left(d_{1}\right)=0.794$

$N\left(d_{2}\right)=0.39$

$\mathrm{C}=\mathrm{S} N\left(d_{1}\right)-K e^{-r t} N\left(d_{2}\right)$

$=4358.1 \times 0.794-8801.24 \times \mathrm{e}^{-0.04 \times 25} \times 0.39$

$=21.971$ millionRMB

\subsubsection{Total value of the project}

The value of the investment project comes not only from the cash flow generated by the project investment, but also from the option value of the future investment opportunities of the project, that is, the total value of the project is equal to the sum of the real option value and NPV ${ }^{[7]}$.

The total value of the case is $\mathrm{NPV}+\mathrm{RO}=56.4$ milion $\mathrm{RMB}$. After considering the value of the real option, the project is worth more investment.

\section{Summary}

1. The crowd-funding mode to solve the financing difficulties of distributed PV power plant, not only can promote energy security and environmental protection concept, but for investors, the investment rate of return 


\section{International Journal of Science and Research (IJSR) \\ ISSN (Online): 2319-7064}

Index Copernicus Value (2015): 78.96 | Impact Factor (2015): 6.391

is attractive.

2. In view of the characteristics of the distributed PV roof project itself, there are many uncertainties. Therefore, the value of the project is calculated by the net present value method, which only reflects the value of one part, and another part of its value that future growth opportunities cannot be reflected. Therefore, the idea of using real options can provide investors with the means to capture potential investment opportunities in view of the uncertainties in investment. The real option theory is applied to the investment decision of PV project, and the investment value of the project is revised on the basis of the traditional NPV method, so that the investors can make more scientific and reasonable investment decision.

\section{References}

[1] Evans A, Strezov V\&Evans TJ . Assessment of sustainability indicators for renewable energy technologies [J]. Renewable and Sustainable Energy Reviews, 2009, 13( 5) .

[2] Kate D.Latham. Economic analysis of photovoltaic systems for local governments in California[D].America. San Jose State University.2004:11.

[3] Rolf Wustenhagen , Maarten Wolsink\&Mary Jean Burer . Social acceptance of renewable energy innovation: An introduction to the concept $[\mathrm{J}]$. Energy Policy, 2007 ( 25) : 2683 - 2691.

[4] Jin Qiang, Shi Zinan. "National economic evaluation of photovoltaic power generation projects[J]. Power for the construction of.2013 (34): $87-90$.

[5] Zhang liang. Study on the fund raising model for the sectors of energy saving and new energy[J].Development Research,2009(7):38-41.

[6] Guo Yi. Research on uncertainty investment decision based on real option theory[D].Central South University, 2006.

[7] Qing Song, Liu Yong. Black. Scholes. The application of option pricing model in enterprise valuation[J]. Academic research, 2004, 9:41-45

\section{Author Profile}

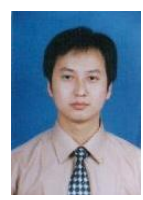

Peng Bo Yang works as an associate professor in school of Economics and Management, XIDIAN University. His specialization lies in consumer finance and behavioral finance.

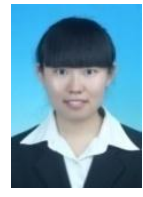

Xinyue Ma is now pursuing Master degree since 2016 under the guidance of Prof. Jiang. Her specialization area is Finance.

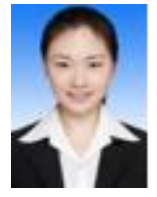

Hao Luo is now pursuing Master degree since 2016 under the guidance of Prof. Jiang. Her specialization area is Finance.

Volume 6 Issue 7, July 2017 www.ijsr.net 